\title{
THE ANALYSIS OF INTENTION TO BUY: AN EXTENDED THEORY OF PLANNED BEHAVIOR
}

\author{
Danu Gilang Pinasthika \\ Management, Economics and Business, Jenderal Soedirman University, Indonesia \\ danugilangp@gmail.com
}

Agus Suroso

Management, Economics and Business, Jenderal Soedirman University, Indonesia agus.suroso@unsoed.ac.id

Siti Zulaikha Wulandari

Management, Economics and Business, Jenderal Soedirman University, Indonesia zulaikhaw@hotmail.com

\begin{tabular}{|c|c|}
\hline Article Info & Abstract \\
\hline $\begin{array}{l}\text { Article History } \\
\text { Received: } \\
20 \text { April } 2021\end{array}$ & $\begin{array}{l}\text { This research is aimed to test an empirical study on UNSOED } \\
\text { Press. The study took the title: "The Analysis of Intention to Buy: } \\
\text { An Extended Theory of Planned Behavior". The purpose of this } \\
\text { research is to know and find empirical evidence of the influence } \\
\text { of Brand Awareness, Price, Attitude, Subjective Norm, Perceived } \\
\text { Behavioral Control of Purchase Intention. The population in this } \\
\text { study were students in Universitas Jenderal Soedirman. The } \\
\text { samples in this study were } 211 \text { person. Sample determination } \\
\text { using the Convenience sampling method. The analysis tool used } \\
\text { is multiple regression. Based on the results of the research and } \\
\text { analysis of data shows that:(1) Brand Awareness has no effect } \\
\text { on Purchase Intention. (2) Price has a positive effect on } \\
\text { Purchase Intention. (3) Attitude has a positive effect on } \\
\text { Purchase Intention. } 4 \text { Subjective Norm has no effect on Purchase } \\
\text { Intention. } 5 \text { Perceived Behavioral control has a positive effect } \\
\text { on Purchase Intention. The implication of the conclusion above } \\
\text { is, UNSOED Press has to build awareness among students or } \\
\text { target market. Promotion from faculty and lecturers must be } \\
\text { improved. Lecturers can provide suggestions for using UNSOED } \\
\text { Press during classroom learning. For the price, respondent said } \\
\text { the price was not too expensive and have to maintance quality. }\end{array}$ \\
\hline & $\begin{array}{l}\text { Keywords: Brand Awareness, Price, Attitude, Subjective Norm, } \\
\text { Perceived Behavioral Control, Purchase Intention, Theory of } \\
\text { Planned Behavior }\end{array}$ \\
\hline
\end{tabular}

\section{INTRODUCTION}

Nowadays, human needs began to increase, starting with the needs of individuals, groups, and companies. The increasing needs of society are proportional to the increasing development of 
technology because technology is now closely related to human activities and can not be released in daily life activities, because in reality, it can facilitate human work, ranging from academia, advertising, communication, and other needs. If viewed from an economic perspective, we can see the increase and diversity of human needs today so that there are opportunities for marketers to meet the needs of the community. This is supported by Yulianita (2001) states that as the community advances, the increasing population, the increasing needs of the community.

According to the Badan Pusat Statistika (BPS), (2019), economic growth can be seen as the increase in the number of goods and services produced by economic activities that exist in a region during the period of a year. Central Java gross Regional product (PDRB) value 2018 on the basis of a constant price of 2010 , reaching 941.28 trillion rupiahs. The figure rose from 893.75 trillion rupiahs in 2017.

In other words, during the year 2018 economic growth occurred at 5.32 percent, whereas gross Regional domestic product (PDRB) is a gross value of all goods and services created or produced in the domestic region of a country arising Due to various economic activities within a given period regardless of whether a resident or non-resident production factor is produced. Seeing that data we can know that economic growth in Central Java is good.

General commercial, quick printing, newspaper printing, book printing, financial, legal printing, screen printing, and digital printing. The printing industry is still growing rapidly, even in the coming years 2020, Printing industry growth in the world reaches USD 47.2 billion. In Indonesia, the printing industry grew to $14.9 \%$ followed by the growth of the packaging industry that rose $13.2 \%$ and the advertising industry 12.1\% (Margomo, 2018). The development of the printing industry is growing rapidly, resulting in very tight competition among the printing industry. They compete to offer a variety of facilities, quality service and the best presentation possible to provide added value to the services and products it offers. This effort is done to survive amid intense competition and remain the main choice for consumers so that they have a loyal customer.

There are many printing companies in Purwokerto right now. They offer facilities \& product that appeal to consumer. UNSOED Press is one of the printing businesses in Purwokerto, located on the campus UNSOED Grendeng Jl. HR. Boeyamin 708 Purwokerto. According to the $1^{\text {st }}$ interview (personal interview, $23^{\text {rd }}$ September 2019), UNSOED Press was established in June 1983, UNSOED received a set of tools and printing machines from the Directorate General of Higher Education to help the task of university. With the issuance of the decree of the Rector of the Jenderal Soedirman University No. KEPT. 116 / PT30.B.1 / C / 1983 dated August 23 ${ }^{\text {th }}, 1983$ under the name "ALUMNI PRINTING OFFSET". UNSOED Press is managed under Unsoed 
Management Agency, on April $3^{\text {rd }} 2018$ there was a collaboration with Sampurna Print Shop so that new machinery was procured to develop potential and open business opportunities.

The services and products provided by UNSOED Press, are photo studio services, printing textbooks, monographs, proceedings. It can be seen that the products and services offered by UNSOED Press varied. In terms of the price offered affordable for students and institutions. UNSOED Press has many competitors, considering the number of printing businesses in Purwokerto, consumers can choose the best one.

The excellence of UNSOED Press are have a strategic location, good printing quality, and can print International Standard Book Number (ISBN) because not all printing business can do it. Not only in printing, but also offering a lot of products like key chains, mugs, pins, stickers, and graduation gifts. Now the mandatory agenda given by the university to the UNOSED Press is to make graduation invitations four times a year, as well as textbooks for new students, with six titles, one book title printed as many as 5,500 copies.

However, According to the $2^{\text {nd }}$ interview (personal interview, $23^{\text {rd }}$ September 2019), the main problem is the lack of marketing promotion so that only a few UNSOED students use this service for printing thesis or organizational activities. Then what of support from universities also affects. In fact, from a total of 13 Faculties at UNSOED, only about two suggested their students to use this service, such as FPIK, FEB Postgraduate, and even that was not too much. Even though the UNSOED Press gives brochures to each faculty every year to promote. This problems causes the sales target can't be optimally fulfilled.

In dealing with these situations, the management of UNSOED Press has to implement the best strategy to attract customers for the intention to buy. Price sensitivity is one of the important factors to determine purchase intention (Hsu et al., 2017). According to (Swasta, 1999), price is the amount of money needed to get a combination of goods and services.

According to Utami \& Saputra (2017) price is several values exchanged to obtain a product for sensitive consumers, usually the perception of low prices and good quality is an important source of satisfaction because they will get high value for money. Prices too high and too low will affect consumer purchase intention, if the price offered too high it will make consumers switch to other similar products but at lower prices, and vice versa, if the price offered is too low, consumers will be doubtful about the quality of the product offered, thereby reducing buying interest in the product (Utami \& Saputra, 2017).

Another factor that affects purchase intention is brand awareness. Correia et al., (2020) states that brands can be used as a source of competitive advantage to attract potential consumers to buy. Having and giving birth to a big and strong brand is certainly the dream of all business 
people. With the strength of a large brand will make it easier for companies to reap revenue and provide a guarantee for the long term future. Nevertheless, the process of building and giving birth to a big brand is not very easy. Bashir (2019) found brand awareness has a significant positive effect on purchase intention.

Aside from both factors, according to Theory of Planned Behavior (TPB) developed by Liu et al. (2020), intentions are built from three main components namely attitudes toward behavior, subjective norms, and perceived behavioral control. Everyone needs to realize that behavioral beliefs, normative beliefs, and control beliefs are influenced by various factors such as personal, cultural, and situation factors.

The TPB has strong explanatory power for individual intention and behavior (Huang \& Ge, 2019). Attitudes represent the positive or negative of an individual in performing the particular behavior of interest. Several studies that research the relationship between attitude towards purchase intention show significantly positive influences (Tan, Ooi, \& Goh, 2017; Huang \& Ge, 2019; Yazdanpanah \& Forouzani, 2015; Zhao, Zhang, \& Wang, 2019; Hart, et al., 2016).

The incompatibility between the consumer attitude and own family and friends' expectancies may additionally determine the consumer intention to select something, this phenomenon is additionally known as the term subjective norm. Furthermore, few studies support the findings of the relationship between subjective norms towards purchase intention (Tan, Ooi, \& Goh, 2017; Choi \& Johnson, 2019; Zhao et al., 2019). On the other hand, research conducted by Yazdanpanah \& Forouzani (2015) and Huang \& Ge (2019) found that subjective norms did not have a significant positive effect on purchase intention.

Several past studies found that perceived behavioral control has positive effects on purchase intention (Tan, et al., 2017; Hsu et al., 2017; Zhao et al., 2019). In contrast, there are some studies found that perceived behavioral control did not have positive effects on purchase intention (Choi \& Johnson, 2019; Yazdanpanah \& Forouzani, 2015; Zerbini et al., 2017). Han, Hsu, \& Sheu (2010) verified that the TPB model is better capable of expect purchase intention than the concept of a reasoned action model (TRA).

\section{Purchase intention}

The intention to buy is consumer behavior when the consumer is stimulated by external factors and decides to buy according to their personal properties and processes (Ajzen \& Fishbein, 1972; Aruan \& Wirdania, 2020). According to Zhao et al. (2019), Intention is a mental state which represents a commitment to future action or actions. Intention includes mental processes such as preparation and analytical thinking. According to (Aruan \& Wirdania, 2020). Purchase intention 
refers to a subjective customer judgment which is expressed in the purchase of a product or service after an in-depth evaluation.

According to Keller (1993), consumer interest is how likely consumers are to buy a brand or how likely the consumer is to move from one brand to another. Whereas Rowley, (1997) found that the function of interest from consumer interests is a function of product quality and service quality.

\section{Brand Awareness}

Brand awareness demonstrates the ability of a prospective buyer to recognize or recall that a brand is part of a particular product category (Rachmawati et al., 2020). Currently according to Rachmawati et al.(2020) brand awareness is a fundamental dimension in brand equity. Based on viewpoints, a brand has no equity until the consumer realizes the existence of the brand.

Brand awareness consists of brand recall and brand recognition, the former represents customers ' ability to recall a brand name, while the latter represents customers ' ability to identify a brand in the presence of a brand cue (Dabbous \& Barakat, 2020). Indicators that characterize the brand awareness are :
a. Consumers ' minds on the brand of a product
b. Easy-to-remember brand
c. Easily recognizable models and their type

\section{Price}

Price is the amount of money charged on a product, or the amount of the value of the consumer exchanged for the benefits of owning or using the product. According to Kotler \& Keller, (2008) and Lahtinen et al., (2020) stating that Price is one of the marketing mixes that generates income, other elements generate costs. Price is the most customizable element of the marketing mix, product traits, distribution channels even promotion takes more time (Lahtinen et al., 2020).

The price also communicates the company's intended value position to the market about the product and its brand. The price is a variable that can be controlled and determine the acceptable or the presence of a product by the consumer. The price depends on the company's policy, but of course, considering the various things. The cheap or expensive price of a product is very relative to its nature. To say it needs to be compared to the price of similar products produced or sold to other companies.

According to (Kotler \& Keller, 2008; Lahtinen et al., 2020), Indicators that characterize the price are:

a. Affordability price.

b. Price suitability with product quality. 
c. Price conformance with benefits.

d. Price affects the purchasing power of consumers.

\section{Theory of Planned Behavior (TPB)}

Theory of Planned Behavior (TPB) or a planned behavioral theory is a continuation of the Theory of Reasoned Action (TRA) that has been examined by Ajzen and Feshebian in 1975 then developed until 1980. Theory of Reasoned Action has a limited inability to handle individual behavior control. The theory of planned behaviour is the intention of individuals to do something given by the level of practice (Liu et al., 2020).

The theory of planned behavior has 3 independent variables. First is the attitude towards behavior in which one assesses something profitable and unprofitable. Second is a social factor called a subjective norm, it refers to the perceived social pressure to commit or not to commit an action. The third antecedent intention is the level of perception of behavioral control, as we saw earlier on the perception of ease or difficulty doing behaviors, and reflects past experiences as anticipation of obstacles and obstacles (Icek Ajzen, 1991).

Theoretically, attitude, behavior, subjective norms, and perceived behavioral control are very different concepts each having an important place in social and behavioral research. Besides, most of the research on the Theory of Reasoned Action (TRA) and the Theory of Planned Behavior (TPB) have clearly defined the utilities of the differences by indicating that different constructions are the relationship between intent and Behavior (Icek Ajzen, 1991).

\section{Attitude}

Attitudes are positive or negative beliefs to present a particular behavior (Shah Alam \& Mohamed Sayuti, 2011). An individual will be interested in presenting a particular behavior when he or she is positive. Attitudes are determined by the individual's belief in the consequences of displaying a behavioral belief, rather than based on the results of an evaluation of its consequences (Rizkitysha \& Hananto, 2020). Attitude is characterized as a psychological tendency expressed by evaluating a specific identity with some degree of favour or disadvantage (Ajzen \& Fishbein, 1972). According to (Han \& Kim, 2010), Indicators that characterize the attitude are :
a. Buying the Product is good idea.
b. Buying the Product is wise choice.
c. Buying the Product is favorable.
d. Buying the Product is pleasant.
e. Buying the Product is positive. 


\section{Subjective Norms}

Icek Ajzen (1991) defined subjective standards as the perceived social pressure to perform the behavior or not to do it (p. 188). subjective norm is the perceived opinions of significant others who are close/important to an individual and who influence his/her decision-making (Han \& Kim, 2010). Subjective norm is how the person perceives the pressure put on him or her to perform or not to perform the behavior (Ajzen \& Fishbein, 1972). This concept is consistent with the measuring things used as adapted from Chen \& Tung (2014). Subjective norm as defined by normative belief is "located within, but not equivalent to, the broader framework of social norms, while social norm refers to a rather wider range of acceptable, but not necessarily necessary, actions" as illustrated by (Ajzen \& Fishbein, 1972).

Normative belief refers to a specific behavioral act whose performance under the given circumstances is expected or desired (Ajzen \& Fishbein, 1972).

According to Taylor \& Todd (1995), Indicators that characterize the attitude are :

a. People around mer use the product, this will prompt me to buy

b. People who are important to me would think that I should buy the product.

\section{Perceive Behavioral Control}

Perceived behavioral control is strongly related to one's beliefs regarding the influence of both situational and internal factors to facilitate performing the behavior (Alam et al., 2014). Perceived conduct control (PBC) is defined as the perceived ease or difficulty of an individual in performing a specific behavior; the concept is very similar to the perceived self-efficacy concept of Bandura (1982) (Icek Ajzen, 1991).

Huang \& Ge (2019) claimed that PBC tests the degree to which a person has the opportunity and ability to perform a behavior. Perceived behavioral control is strongly related to one's beliefs about the influence of both situational and internal factors to facilitate behavioral performance; the more control a person has over the energy-saving product being considered; the more likely it is to be used by that person (Alam et al., 2014).

According to Huang \& Ge (2019), Indicators that characterize the attitude are :

a. Consumer can largely decide whether or not to buy the product.

b. Consumers will have the ability to buy the product.

c. Consumer confident that if they want to, they will definitely be able to choose the product for the next purchase. 
Figure 1. Research Model

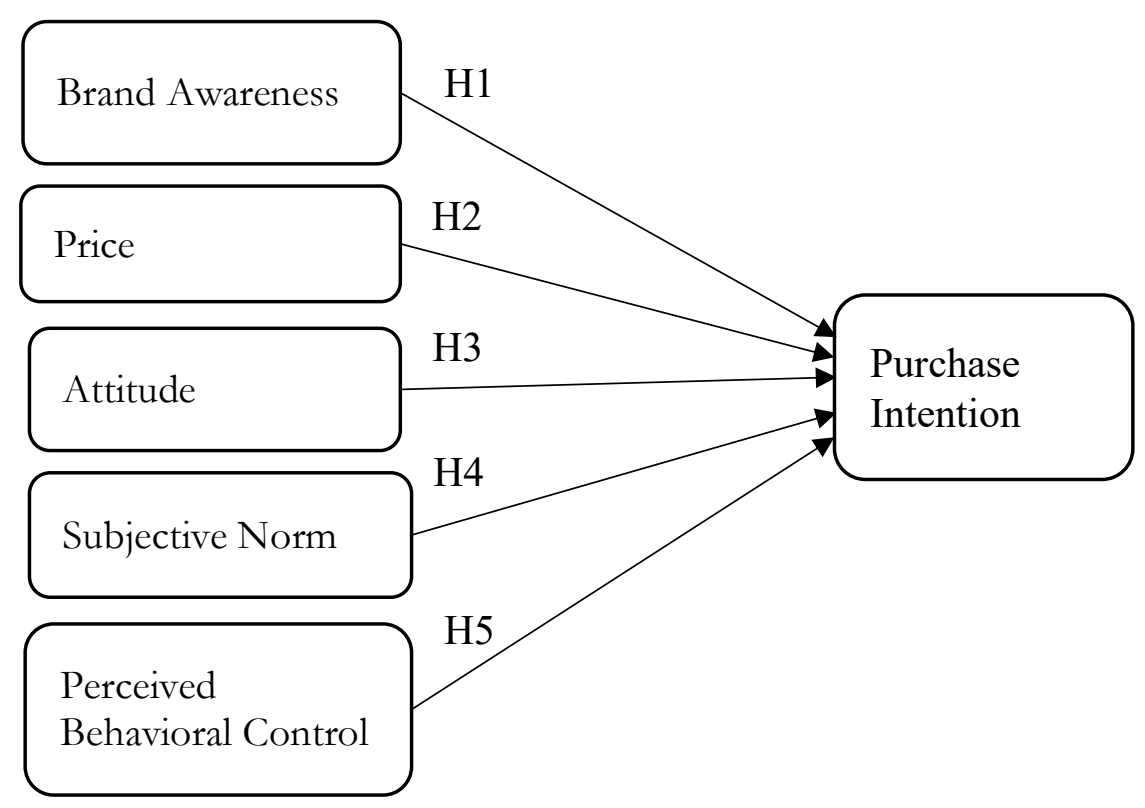

\section{METHOD}

This research is quantitative with survey method by using questionnaires as a tool to obtain the data, means that collecting the data and investigate the casual relationship and hypothesis testing to give an overview of the research object. This research conducted in Purwokerto, Central Java conducted in March 2020 with the subject of this research were students in Universitas Jenderal Soedirman and the objective of this research are brand awareness, price, attitude, subjective norm, and perceived behavioral control.

For sampling technique, based on the calculation, The total population is known to be 20.270 based on 2019/2020 final voter list of student executive board. If the probability of error is set at $10 \%$, then the minimum sample size can be calculated as follows:

$$
n=\frac{20.270}{1+20.270(0.1)^{2}}=99,51
$$

Based on the calculation results obtained the minimum number of samples is as much as 99.51 . This study will take a sample of 211 respondents.

The method of selecting samples in this study was carried out by convenenience sampling method, Techniques of sampling based on coincidence, population members who are found researchers and willing to become respondents as samples. 


\section{RESULTS}

Table 1 Respondent Characteristics by Faculty

\begin{tabular}{|c|c|c|}
\hline Faculty & Quantity (Person) & Percentage \\
\hline Faculty of Agriculture & 29 & 14 \\
\hline Faculty of Health Sciences & 20 & 9 \\
\hline Faculty of Engineering & 16 & 8 \\
\hline Faculty of Biology & 10 & 5 \\
\hline Faculty of Animal Husbandry & 15 & 7 \\
\hline Faculty of Social Science and Political Science & 23 & 11 \\
\hline Faculty of Fisheries and Marine Sciences & 8 & 4 \\
\hline Faculty of Law & 20 & 9 \\
\hline Faculty of Economics and Business & 34 & 16 \\
\hline Faculty of Mathematics and Natural Sciences & 10 & 5 \\
\hline Faculty of Cultural Science & 18 & 9 \\
\hline Faculty of Medicine & 8 & 4 \\
\hline Total & 211 & 100 \\
\hline
\end{tabular}

Table 1 shows the amount of respondents from each faculty, the questionnaire is distributed using proportional convenience sampling, the higher the population of each existing faculty, will increase the number of samples in it. The table shows that the most populated faculty is Economics and Business, followed by Agriculture, and Social and Political sciences.

\section{Respondent Characteristic by Acknowledgement of UNSOED Press}

Table 2. Show Respondent's Acknowledgement about The Existence of UNSOED Press

\begin{tabular}{|l|c|c|}
\hline Indicators & Quantity (Person) & Percenatage \\
\hline Acknowledege & 166 & 78,67 \\
Unacknowledgede & 45 & 21,33 \\
\hline \multicolumn{1}{|c|}{ Total } & $\mathbf{2 1 1}$ & $\mathbf{1 0 0 , 0 0}$ \\
\hline
\end{tabular}

According to the data above, it can be conclude that majority of the respondents in this research have an acknowledgement of UNSOED Press with percentage 78,67\% with number of respondents 166 person. At the same time, the respondents that does not have an acknowledgement is $21,33 \%$ with number of respondents 45 person.

\section{Classical Assumption Test}

\section{Normality Test}

Normality test is done by the Kolmogorov Smirnov test, with the criteria if the asymptotic significant $>$ alpha value $(\alpha=0.05)$ then the data are normally distributed. 
Table 3. One- Sample Kolmogorov- Smirnov Test

\begin{tabular}{|l|l|}
\hline \multirow{2}{*}{ Asymp. Sig. } & Unstandardized Residual \\
\cline { 2 - 2 } & 0.200 \\
\hline
\end{tabular}

According to Table 3, the value of Asymp. Sig. is 0,200 that is higher than 0.05 which means that the data are normally distributed.

\section{Heteroscedasticity test}

The heteroscedasticity test is to determine the variance differences from residual in an observation with other observations. Table 4 provides the result of heteroscedasticity test.

Table 4. Heteroscedasticity Test Result

\begin{tabular}{|l|l|l|}
\hline Variable & SIG & Result \\
\hline Brand Awareness & 0.667 & No Heteroscedasticity \\
Price & 0.812 & No Heteroscedasticity \\
Attitude & 0.828 & No Heteroscedasticity \\
Subjective Norm & 0.519 & No Heteroscedasticity \\
Perceived Behavioral Control & 0,811 & No Heteroscedasticity \\
\hline
\end{tabular}

Table 4 shows that all significance values of each variable are higher than 0.05 , which means that there is no heteroscedasticity problem on the data.

\section{Multicollinearity Test}

Multicollinearity testing is to examine whether there is an existence of a high correlation between the independent variables. Table 5 shows the result of multicollinearity test.

Table 5. Multicollinearity Test Result Model

\begin{tabular}{|l|l|l|l|}
\hline Variable & Tolerance & VIF & Result \\
\hline Brand Awareness & 0,837 & 1,195 & No multicollinearity \\
Price & 0,595 & 1,681 & No multicollinearity \\
Attitude & 0,566 & 1,767 & No multicollinearity \\
Subjective Norm & 0,832 & 1,202 & No multicollinearity \\
Perceived Behavioral & 0,820 & 1,220 & No multicollinearity \\
Control & & & \\
\hline
\end{tabular}

Table 5 shows that each collinearity tolerance values of each variable are higher than 0.1 and the VIF values of each variable are lower than 10 which means that there is no multicollinearity problem on the data.

\section{Hypothesis Testing}

\section{Coefficient of Determination $\left(R^{2}\right)$}

The coefficient of determination $\left(\mathrm{R}^{2}\right)$ test is to analyze the regression line to describe the relationship between the independent variables and dependent variable. Table 7 shows the coefficient of determination $\left(\mathrm{R}^{2}\right)$ result. 
Table 6. Coefficient of determination $\left(\mathrm{R}^{2}\right)$ Test Result

\begin{tabular}{|l|l|l|l|l|}
\hline Model & $\mathrm{R}$ & R Square & Adjusted R Square & $\begin{array}{l}\text { Std. Error of the } \\
\text { Estimate }\end{array}$ \\
\hline 1 & 0,759 & 0,576 & 0,566 & 1,738 \\
\hline
\end{tabular}

a.Predictors: (Constant), X5, X1, X4, X2, X3

From Table 6 it can be concluded that the variable of Brand Awareness, Price, Attitude, Subjective Norm, and Perceived Behavioral Control explain the Purchase Intention in UNSOED Press by 0.576 or $57.6 \%$, while 0.424 or $42.4 \%$ are explained by other variables not included in the model

F - Test

Table 7. F Test Result

\begin{tabular}{|l|l|l|l|l|l|}
\hline Model & Sum of Squares & Df & $\begin{array}{l}\text { Mean } \\
\text { Square }\end{array}$ & F & Sig. \\
\cline { 1 - 3 } $\begin{array}{l}\text { Resression } \\
\text { Residual }\end{array}$ & 842,041 & 5 & $\begin{array}{l}168,408 \\
3,021\end{array}$ & & \\
\cline { 1 - 4 } Total & 619,390 & 205 & & 55,738 & .000 \\
\hline
\end{tabular}

a. Dependent Variable: Purchase Intention (Y)

b. Predictors: (Constant), X5, X1, X4, X2, X3

From the results of multiple regression analysis in Table 7 and it can be seen that the value of Fstatistic of 55,738 is higher than the value of $\mathrm{F}$ table 2,26. So, it can be explained Brand Awareness, Price, Attitude, Subejctive Norm, and Perceived Behavioral Control simultaneously affect Purchase Intention in UNSOED Press. It can be stated that multiple regression models in this research is accordance with the research data (goodness of fit).

T - Test

Table 8. T-Test Result

\begin{tabular}{|c|c|c|c|c|c|}
\hline No & Hypotheses & $\mathbf{T}$ & $\mathrm{t}$ - table & Significance & Result \\
\hline 1 & $\begin{array}{l}\text { Brand Awareness } \rightarrow \\
\text { Purchase Intention }\end{array}$ & $-0,665$ & 1,652 & 0,507 & Rejected \\
\hline 2 & $\begin{array}{l}\text { Price } \rightarrow \text { Purchase } \\
\text { Intention }\end{array}$ & 4,659 & 1,652 & 0,000 & Accepted \\
\hline 3 & $\begin{array}{l}\text { Attitude } \rightarrow \text { Purchase } \\
\text { Intention }\end{array}$ & 7,110 & 1,652 & 0,000 & Accepted \\
\hline 4 & $\begin{array}{l}\text { Subjective Norm } \rightarrow \\
\text { Purchase Intention }\end{array}$ & 1,909 & 1,652 & 0,058 & Rejected \\
\hline 5 & $\begin{array}{l}\text { Perceived Behavioral } \\
\text { Control } \rightarrow \text { Purchase } \\
\text { Intention }\end{array}$ & 3,830 & 1,652 & 0,000 & Accepted \\
\hline
\end{tabular}


Table 8 shows that the $\mathrm{t}$ - statistic of Brand Awareness (-0.665) towards purchase intention is lower than the value of $\mathrm{t}$ - table (1.652) and the value of error probability (0.507) is higher than 0.05 , which makes $\mathrm{H}_{0}$ hypothesis rejected. The $\mathrm{t}-$ statistic of Price $(4,659)$ towards purchase intention is higher than the value of $t$ - table (1.652) and the value of error probability (0.00) is lower than 0.05 , which makes $\mathrm{H}_{0}$ hypothesis accepted. The $\mathrm{t}$ - statistic of Attitude $(7,110)$ towards purchase intention is higher than the value of $\mathrm{t}-$ table $(1,652)$ and the value of error probability $(0.000)$ is lower than 0.05 , which makes $\mathrm{H}_{0}$ hypothesis accepted. The $\mathrm{t}$ - statistic of subjective norm control $(1,909)$ towards purchase intention is lower than the value of $\mathrm{t}$ - table $(1,652)$ and the value of error probability $(0,058)$ is higher than 0.05 , which makes the H0 hypothesis rejected. The $\mathrm{t}$ statistic of Perceived Behavioral Control $(3,830)$ towards purchase intention is higher than the value of $\mathrm{t}$ - table $(1,652)$ and the value of error probability $(0,000)$ is lower than 0.05 , which makes $\mathrm{H}_{0}$ hypothesis accepted.

\section{DISCUSSION}

\section{Effect of Brand Awareness on Purchase Intention}

Finding of this research proved that brand awareness has no effect on purchase intention. This relationship means that the better level of brand awareness is not always followed by the better level of purchase intention on UNSOED Press.

The reason why brand awareness has no effect on purchase intention can be seen according frequency distribution item number two, three and four. Item number two "You are familiar with UNSOED Press", 38 respondents (18\%) were strongly disagree, 66 respondents $(31,3 \%)$ were disagree, 81 respondents $(38,4 \%)$ were neutral. Only 20 respondents $(9,5 \%)$ and 6 respondents $(2,8 \%)$ that were each chose agree and strongly agree for the statement. A total of 104 respondents (consist of 38 strongly disagree respondents and 66 disagree respondents) from a total of 211 respondents explains the lack of students familiarity about UNSOED Press. According to item number three "UNSOED Press is a popular digital printing", 30 respondents $(14,2 \%)$ were strongly disagree, 73 respondents $(34,6 \%)$ were disagree, 98 respondents $(46,4 \%)$ were neutral. Only 20 respondents $(4,7 \%)$ that chose agree and 0 respondent chose strongly agree for the statement. From 211 respondents only 20 (4.7\%) of them agree that UNSOED Press is popular and not even any of the participant strongly agrees with the statement. So it can be concluded that UNSOED Press is not popular in student environment.

According to item number four "Products and services from UNSOED Press can be recognize based on its model and type", 21 respondents (9,9\%) were strongly disagree, 68 respondents $(32,2 \%)$ were disagree, 99 respondents (47\%) were neutral. Only 18 respondents 
$(8,5 \%)$ and 5 respondents $(2,4 \%)$ that were each chose agree and strongly agree for the statement. Only 23 respondents (consist of 18 agree respondents and 5 strongly agree respondents) from a total of 211 respondents state that products and services of UNSOED Press can be easily recognized. Means the majority of the respondent find it complicated to recognize.According to qualitative data from this research some students do not know what services and products provided by UNSOED Press, this is caused by a lack of promotion.

Majority of respondents argue that the building of UNSOED Press did not reflect digital printing like the competitors such as Zuper, Ortindo, and Appolo, moreover the enclosed building made consumers unable to see the activities inside, therefore the consumers were not aware of the presence of UNSOED Press. Based on the analysis of the three items and the open question we can see the reason why brand awareness has no effect on purchase intention. In this research, the result is different with the previous study by Bashir (2019) show that brand awareness has a positive effect on purchase intention.

\section{The Effect of Price on Purchase Intention}

Finding of this research proved that price has a positive effect on purchase intention. It means that the better level of price product, the greater level of purchase intention. Price has a positive and significant effect on purchase intention. This shows that price plays an important role in enhancing purchase intention in UNSOED Press. To find out more about variable price, according to qualitative data from this research, respondent thought that the offered price already accordance to the purchasing power of students and can be competitive enough with other competitor.

Proven by frequency tabulation (Appendix 2) about Price as written in item number one "product/service fee that being offered by UNSOED Press is in line with my expectation", 76 respondents (36\%) were neutral, 95 respondents (45\%) were agree, and 19 respondents $(9 \%)$ were strongly agree. Empirically the result of this study is consistent with the the results of research from Diallo (2012) and Erdil (2015), shows that price has a positive effect on Purchase Intention.

\section{The Effect of Attitude on Purchase intention}

Finding of this research proved that attitude has a positive effect on purchase intention. It means that the better level of attitude, the greater level of purchase intention. This shows that attitude plays an important role in enhancing purchase intention.

To find out more about Attitude, according to qualitative data from this research, respondents thought that buying product here is good attitude towards UNSOED Press. This is in line with the frequency tabulation (Appendix 2) where the average respondents thought that buying products and services in UNSOED Press is a wise, profitable, fun, positive and a good 
idea. Empirically the result of this study is consistent with the previous research by Zhao et al. (2019) and Hoeksma, Gerritzen, Lokhorst, \& Poortvliet (2017) who found that Attitude has positive effect towards purchase intention.

\section{The Effect of Subjective Norm on Purchase Intention}

Finding of this research proved that subjective norm has no effect on purchase intention. This relationship means that the better level of subjective norm is not always followed by the better level of purchase Intention.

The reason why subjective norm has no effect on purchase intention can be seen according to qualitative data from this research, respondents thought what can influence them to use products/services in UNSOED Press are friends and influential people in their life. Meanwhile based on the frequency distribution item number three and four. Item number three "Influential lecturer advise me to use UNSOED Press services and products", 9 respondents (4,3\%) were strongly disagree, 46 respondents $(21,8 \%)$ were disagree, 83 respondents $(39,3 \%)$ were neutral, 55 respondents $(26,1 \%)$ were agree and 18 respondents $(8,5 \%)$ were strongly agree. Only 73 respondents (consist of 55 agree respondents and 18 strongly agree respondents) from a total of 211 respondents that were given advice by lecturers to use UNSOED Press, means that there was a lack of lecturer support student to use UNSOED Press product and services. Than item number four that "Society of Academicians advise me to use UNSOED Press services and procuts", 26 respondents $(12,3 \%)$ were strongly disagree, 53 respondents $(25,1 \%)$ were disagree, 73 respondents $(34,6 \%)$ were neutral, 41 respondents $(19,4 \%)$ were agree and 18 respondents $(8,5 \%)$ were strongly agree.

Only 59 respondents (consist of 41 agree respondents and 18 strongly agree respondents) from a total of 211 respondents that were given advice by society of academicians to use UNSOED Press, means that there was a lack of society of academicians support students to use UNSOED Press product and services. Based on the analysis of two items and the open question can be conclude that the lack of advice from lecturers and the campus makes subjective norm has no effect on purchase intention.

In this research shows the opposite finding from Theory of Planned of Behavior stating that subjective norm has positive effect on behavioral intention such as purchase intention. According to Tan et al (2017) and Zhao et al. (2019) who found that subjective norm has positive effect towards purchase intention. On the other hand this research correlate with Huang \& Ge (2019) and Yazdanpanah \& Forouzani (2015), who found that subjective norm has no effect toward purchase intention. 


\section{The Effect of Perceived Behavioral Control on Purchase Intention}

Finding of this research proved that perceived behavioral control has a positive effect on purchase intention. It means that the higher level of perceived behavioral control on product, the stronger customers' intention to purchase. This shows that perceived behavioral control plays an important role in enhancing intenton to buy. To find out more about perceived behavioral control, according to qualitative data from this research, the majority of the respondent said that they could have the capability, capacities, and desire to use UNSOED Press services if they want it. This is in line with the result pattren from frequency tabulation (Appendix 2). This shows the correlate finding from the Theory of Planned of Behavior stating that perceived behavioral control has a positive effect on behavioral intention such as purchase intention. This finding correlates with Zhao et al. (2019) and Hoeksma et al. (2017) who found that perceived behavioral control has positive effect towards purchase intention.

\section{Effect of Theory of Planned Behavior on Purchase Intention}

In this study, the Theory of Planned Behavior model was successful as a testing model, it can analyze purchase intention in UNSOED Press by predicting individual behavior. This is correlate with Ajzen (1987), Theory of Planned Behavior (TPB) is intended to predict individual behavior more specifically. Although variable subjective norms did not affect purchase intention, researchers get information related to the reasons why subjective norms did not affect to purchase intention, this information can support in increasing purchase intention or in making future strategies.

Even though in this study brand awareness and subjective norm variables did not affect to purchase intention, it does not mean that these variables are not suitable in this research model. With no affect on purchase intention, researchers can identify level on consumer awareness in our brand, whether our promotions can be remembered by the target market, what consumers think about our brand, and the reason why these variable did not affect. It can be process into information and use as suggestions for the future. Therefore, brand awareness and subjective norm variables are suitable in this research model. This is correlate with Icek Ajzen (1991) said, that TPB is suitable to explain any behavior which requires planning, such as entrepreneurship. And correlate with Shimp (2003), brand awareness shows the ability of consumers to recognize and recall the brand, and which part of a certain product category .

According to qualitative data based on open questions, there are several interesting in the result of respondents. In question "what comes to your mind about UNSOED Press", 58 respondents out of 211 answered that they did not know about that, one of respondent said "A type of printing managed by UNSOED. Maybe in terms of promotion it was not intense because 
in my opinion some of the students were still unfamiliar with UNSOED Press" and another said "The printing company is managed by an UNSOED but has not found a suitable marketing system". Based on the t-test and qualitative data, brand awareness was rejected because respondents did not have awareness of UNSOED Press. This is caused by many factor, one of them is lack intensity in advertise the product so consumers did not aware to the brand.

Whereas in the Subjective norm variable, if we look through qualitative data based on open question. The question is "who can influence you in using UNSOED press services", as many as 186 respondents said that friends, the environment, lecturers, and the faculty could influence them in using UNSOED Press services. However, on quantitative data, respondents felt that there was a lack of advice given from the campus and lecturers. So that is the reason why subjective norms do not affect purchase intention at UNSOED Press.

To improve the model in this study, it can add another variables that may influence to purchase intention at UNSOED Press, so the information obtained will be rich and also specific depend on what variables want to add.

\section{CONCLUSION}

Based on the result on this research and discussion, this research is summarized as follows:

1. Brand awareness has no effect on purchase intention.

2. Price has a positive effect on purchase intention.

3. Attitude has a positive effect on purchase intention.

4. Subjective norm has no effect on purchase intention.

5. Perceived behavioral control has a positive effect on purchase intention.

\section{REFERENCES}

Ajzen, I. (1987). Attitudes, traits, and actions: Dispositional prediction of behavior in personality and social psychology. Advances in Experimental Social Psychology, 20(C). https://doi.org/10.1016/S0065-2601(08)60411-6

Ajzen, I., \& Fishbein, M. (1972). Attitudes and normative beliefs as factors influencing behavioral intentions. Journal of Personality and Social Psychology, 21(1). https://doi.org/10.1037/h0031930

Alam, S. S., Nik Hashim, N. H., Rashid, M., Omar, N. A., Ahsan, N., \& Ismail, M. D. (2014). Small-scale households renewable energy usage intention: Theoretical development and empirical settings. Renewable Energy, 68. https://doi.org/10.1016/j.renene.2014.02.010

Aruan, D. T. H., \& Wirdania, I. (2020). You are what you wear: examining the multidimensionality of religiosity and its influence on attitudes and intention to buy Muslim fashion clothing. Journal of Fashion Marketing and Management, 24(1), 121-136. https://doi.org/10.1108/JFMM04-2019-0069 
Badan Pusat Statistika (BPS). (2019). Sosial dan kependudukan. https://www.bps.go.id/publication/2019/07/04/daac1ba18cae1e90706ee58a/statistikindonesia-2019.html

Bashir, A. M. (2019). Effect of halal awareness, halal logo and attitude on foreign consumers' purchase intention. British Food Journal, 121(9), 1998-2015. https://doi.org/10.1108/BFJ01-2019-0011

Chen, M. F., \& Tung, P. J. (2014). Developing an extended Theory of Planned Behavior model to predict consumers' intention to visit green hotels. International Journal of Hospitality Management, 36. https://doi.org/10.1016/j.ijhm.2013.09.006

Choi, D., \& Johnson, K. K. P. (2019). Influences of environmental and hedonic motivations on intention to purchase green products: An extension of the theory of planned behavior. Sustainable Production and Consumption, 18. https://doi.org/10.1016/j.spc.2019.02.001

Correia, R. J., Dias, J. G., \& Teixeira, M. S. (2020). Dynamic capabilities and competitive advantages as mediator variables between market orientation and business performance. Journal of Strategy and Management, 14(2), 187-206. https://doi.org/10.1108/JSMA-12-20190223

Dabbous, A., \& Barakat, K. A. (2020). Bridging the online offline gap: Assessing the impact of brands' social network content quality on brand awareness and purchase intention. Journal of Retailing and Consumer Services, 53. https://doi.org/10.1016/j.jretconser.2019.101966

Diallo, M. F. (2012). Effects of store image and store brand price-image on store brand purchase intention: Application to an emerging market. Journal of Retailing and Consumer Services, 19(3). https://doi.org/10.1016/j.jretconser.2012.03.010

Erdil, T. S. (2015). Effects of Customer Brand Perceptions on Store Image and Purchase Intention: An Application in Apparel Clothing. Procedia - Social and Behavioral Sciences, 207. https://doi.org/10.1016/j.sbspro.2015.10.088

Han, H., Hsu, L. T. (Jane), \& Sheu, C. (2010). Application of the Theory of Planned Behavior to green hotel choice: Testing the effect of environmental friendly activities. Tourism Management, 31(3). https://doi.org/10.1016/j.tourman.2009.03.013

Han, H., \& Kim, Y. (2010). An investigation of green hotel customers' decision formation: Developing an extended model of the theory of planned behavior. International Journal of Hospitality Management, 29(4). https://doi.org/10.1016/j.ijhm.2010.01.001

Hoeksma, D. L., Gerritzen, M. A., Lokhorst, A. M., \& Poortvliet, P. M. (2017). An extended theory of planned behavior to predict consumers' willingness to buy mobile slaughter unit meat. Meat Science, 128. https://doi.org/10.1016/j.meatsci.2017.01.011

Hsu, C. L., Chang, C. Y., \& Yansritakul, C. (2017). Exploring purchase intention of green skincare products using the theory of planned behavior: Testing the moderating effects of country of origin and price sensitivity. Journal of Retailing and Consumer Services, 34. https://doi.org/10.1016/j.jretconser.2016.10.006

Huang, X., \& Ge, J. (2019). Electric vehicle development in Beijing: An analysis of consumer purchase intention. Journal of Cleaner Production, 216. 
https://doi.org/10.1016/j.jclepro.2019.01.231

Icek Ajzen. (1991). The Theory of Planned Behavior Organizational Behavior and Human Decision Processes. Organizational Behavior and Human Decision Processes, 50(2).

Keller, K. L. (1993). Conceptualizing, Measuring, and Managing Customer-Based Brand Equity. Journal of Marketing, 57(1). https://doi.org/10.1177/002224299305700101

Kotler, P., \& Keller, K. L. (2008). Manajemen Pemasaran (1st ed.). Erlangga.

Lahtinen, V., Dietrich, T., \& Rundle-Thiele, S. (2020). Long live the marketing mix. Testing the effectiveness of the commercial marketing mix in a social marketing context. Journal of Social Marketing, 10(3), 357-375. https://doi.org/10.1108/JSOCM-10-2018-0122

Liu, M. T., Liu, Y., \& Mo, Z. (2020). Moral norm is the key: An extension of the theory of planned behaviour (TPB) on Chinese consumers' green purchase intention. Asia Pacific Journal of Marketing and Logistics, 32(8), 1823-1841. https://doi.org/10.1108/APJML-05-2019-0285

Margomo, K. (2018). Formulasi Bersaing Perusahaan Digital Printing. Agora, 6(2), 1-6.

Rachmawati, E., Suliyanto, S., \& Suroso, A. (2020). A moderating role of halal brand awareness to purchase decision making. Journal of Islamic Marketing. https://doi.org/10.1108/JIMA-052020-0145

Rizkitysha, T. L., \& Hananto, A. (2020). "Do knowledge, perceived usefulness of halal label and religiosity affect attitude and intention to buy halal-labeled detergent?" Journal of Islamic Marketing. https://doi.org/10.1108/JIMA-03-2020-0070

Rowley, J. (1997). Beyond service quality dimensions in higher education and towards a service contract. Quality Assurance in Education, 5(1), 7-14.

Shah Alam, S., \& Mohamed Sayuti, N. (2011). Applying the Theory of Planned Behavior (TPB) in halal food purchasing. International Journal of Commerce and Management, 21(1). https://doi.org/10.1108/10569211111111676

Swasta, B. (1999). Azas-Azas Marketing. Yogyakarta: Liberti, 3.

Tan, C. S., Ooi, H. Y., \& Goh, Y. N. (2017). A moral extension of the theory of planned behavior to predict consumers' purchase intention for energy-efficient household appliances in Malaysia. Energy Policy, 107. https://doi.org/10.1016/j.enpol.2017.05.027

Taylor, S., \& Todd, P. A. (1995). Understanding information technology usage: A test of competing models. Information Systems Research, 6(2). https://doi.org/10.1287/isre.6.2.144

Utami, R. P., \& Saputra, H. (2017). Pengaruh Harga Dan Kualitas Produk Terhadap Minat Beli Sayuran Organik Di Pasar Sambas Medan. Niagawan, 6(2). https://doi.org/10.24114/niaga.v6i2.8334

Yazdanpanah, M., \& Forouzani, M. (2015). Application of the Theory of Planned Behaviour to predict Iranian students' intention to purchase organic food. Journal of Cleaner Production, 107. https://doi.org/10.1016/j.jclepro.2015.02.071

Yulianita, N. (2001). Media Massa dan Gaya Hidup Wanita. Mimbar: Jurnal Sosial Dan Pembangunan, 
17(3), 301-327. https://www.neliti.com/publications/157615/media-massa-dan-gayahidup-wanita

Zerbini, C., Luceri, B., \& Vergura, D. T. (2017). Leveraging consumer's behaviour to promote generic drugs in Italy. Health Policy, 121(4). https://doi.org/10.1016/j.healthpol.2017.01.008

Zhao, C., Zhang, M., \& Wang, W. (2019). Exploring the influence of severe haze pollution on residents' intention to purchase energy-saving appliances. Journal of Cleaner Production, 212. https://doi.org/10.1016/j.jclepro.2018.12.134 